\title{
Correction: Unbehagen: a gallantry with excess
}

\section{Cindy Zeiher ${ }^{1}$}

Correction to: Palgrave Communications https://doi.org/10.1057/s41599-017-0035-y, published online 28 November 2017

The original version of the article contained two figures (Fig. 1 and Fig. 2) which appeared in the incorrect order. The order of the two images has now been changed so that the correct image appears with the caption for Fig. 1 and the correct image appears with the caption for Fig. 2.

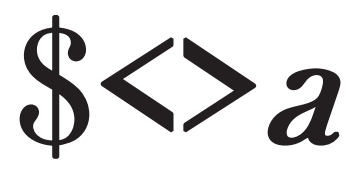

Fig. 1 Lacan's matheme for the structure of fantasy

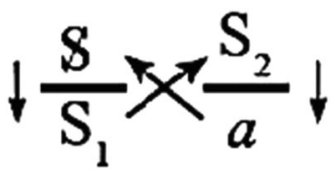

Fig. 2 Lacan's structure of the capitalist discourse

These errors have now been corrected in the HTML and PDF versions of the paper.

Published online: 04 April 2018

(i) Open Access This article is licensed under a Creative Commons Attribution 4.0 International License, which permits use, sharing, adaptation, distribution and reproduction in any medium or format, as long as you give appropriate credit to the original author(s) and the source, provide a link to the Creative Commons license, and indicate if changes were made. The images or other third party material in this article are included in the article's Creative Commons license, unless indicated otherwise in a credit line to the material. If material is not included in the article's Creative Commons license and your intended use is not permitted by statutory regulation or exceeds the permitted use, you will need to obtain permission directly from the copyright holder. To view a copy of this license, visit http://creativecommons.org/licenses/by/4.0/.

(C) The Author(s) 2018

\footnotetext{
${ }^{1}$ School of Language, Social and Political Sciences, University of Canterbury, Christchurch, New Zealand. Correspondence and requests for materials should be addressed to C.Z. (email: cindy.zeiher@canterbury.ac.nz)
} 